\title{
War Rape: New Conceptualizations and Responses
}

\section{Nancy Farwell}

This article presents new conceptualizations of war rape in international law and defines rape as a weapon and strategy of war. It also outlines the intersections of gender, patriarchy, militarism, and ethnic, religious, and political identities that fuel war rape as part of a continuum of violence against women. Local and transnational examples of women's responses to war rape demonstrate their importance to survivors, practitioners, and policy makers who seek to address its causes and effects. Finally, the article challenges feminist social workers to address the dynamics of war rape within the complex nexus of policies that fuel conflict.

Keywords: war; rape; sexual violence; gender relations; rape as a weapon of war

War rape and sexual violence have a history as long as the practice of war itself, yet until recently, they have been absent in discussions of international humanitarian law. Seldom prosecuted and rarely denounced, sexual assault of women committed during conflict situations has been viewed as a byproduct of wartime activity, as "collateral damage" and "spoils of war," not as a violation of humanitarian law (Brownmiller, 1975; Enloe, 2000). The persistent dismissal and mischaracterization of war rape as a personal sexual act, as a "just reward" for "boys [who] will be boys," or even as "inevitable pillage" have reinforced its acceptance as a natural, if regrettable, aspect of war, rather than as a crime under humanitarian law. Implicit tolerance by military and political leaders signifies implicit permission; condemnation and censure are rare, even by those leaders who are in a position to stop war rape. Accepting rape as an inevitable aspect of armed conflict can lead to condoning it and thereby to an overt strategy that utilizes rape as a weapon of war. 
Knowledge of war rape is not new; neither are the minimization, denial, and silencing of these violent acts and the women who have endured them. But two changes over the past several decades are crucial to understanding women's response to war rape and to meeting the challenge to social work. First, awareness of war rape used as a policy-based attack against civilians is recent, and its use requires us to consider it as a weapon, a targeted act of terror, rather than merely as a byproduct of the violence surrounding war (Card, 1996; Coomaraswamy, 1998; Koo, 2002; Olujic, 1998; Seifert, 1996; UNICEF, 1996). Militaries and insurgency groups have increasingly used rape as a weapon, systematically targeting women in the enemy group to achieve political objectives such as ethnic cleansing, genocide, and occupation of enemy territory. International media, feminist activists, and scholars have begun to bring public attention to the use of rape as a weapon during armed conflict. War rape is widespread, taking place under military and civilian rule, its effects felt on virtually every continent. Documented examples include the rape and murder of Chinese women during the Japanese occupation of Nanking (Chang, 1997), the rape of Vietnamese women by U.S. troops during the U.S. war in Vietnam (Brownmiller, 1975), the rape and sexual enslavement of Muslim women in Bosnia-Herzegovina by Serbian forces (Stiglmayer, 1993), the rape of Eritrean women by Ethiopian soldiers (Legesse, 2000; von Kerenshazy, Tekle, Higo, Gottlieb, \& Aradom, 2002), and rape occurring as state-sponsored violence during intrastate conflicts in Rwanda (Twagiramariya \& Turshen, 1998), Guatemala (Archdiocese of Guatemala, 1999), and Burma (Apple \& Martin, 2003).

Second, the emerging conceptualization of war rape as a crime in international law for the first time affords survivors, practitioners, and legal advocates the opportunities and tools to counteract the widespread denial and silencing of war rape and its victims. This article summarizes recent decisions, particularly those emanating from the International Criminal Tribunal for Rwanda (ICTR) and the International Criminal Tribunal for the former Yugoslavia (ICTY), that established legal definitions and precedents for prosecuting perpetrators of war rape and defining war rape as a crime against humanity. It also outlines the complex intersections of gender, patriarchy, militarism, and ethnic, religious, and political identities that underlie a continuum of violence against women, including war rape.

Women have mobilized and responded to war rape within local, regional, and international circles in multiple ways, such as the provision of care and therapeutic interventions, mobilization of media attention to the atrocities, fund-raising for direct assistance, scholarship, advocacy, education, and the formation of solidarity networks. Examples of these efforts indicate their importance to the survivors and their communities, to practitioners who work with survivors, and to policy makers who, through strategic political and legislative means, seek to redress the complex inequalities that often fuel war rape. Finally, this article challenges feminist social workers to 
address the dynamics of war rape within the complex nexus of policies that fuel conflict.

Although war rape is part of a larger category of sexual persecution and terror that includes sexual torture and sexual enslavement, these are related concerns that are beyond the scope of this article. Also, although men and boys may be victims of war rape, women and girls are by far the more common targets. Rape during wartime may also occur within an identity group and by the military within its own ranks; however, for this discussion, the term war rape refers to an act of aggression by one nation or faction against another.

\section{ESTABLISHING WAR RAPE AS A CRIME AGAINST HUMANITY}

In spite of its long history of widespread occurrence, the systematic use of rape in war has only recently been established as a war crime. The Geneva Convention Relative to the Protection of Civilian Persons in Time of War (1949, pp. 287-288) states that "women shall be especially protected against any attack on their honour, in particular against rape, enforced prostitution, or any form of indecent assault," although this language does not fully establish the parameters of rape as a war crime in international law. Due in large part to the dedicated efforts of Asian feminist activists and jurists in the early 1990s, the international legal and humanitarian community finally recognized the human rights violations against more than 200,000 women who had been sexually enslaved more than 50 years earlier by the Japanese military during World War II (Chinkin, 2001). Recognition of these violations spurred the United Nations Sub-Commission on Prevention of Discrimination and Protection of Minorities (within the United Nations Economic and Social Council's Commission on Human Rights) to conduct an in-depth study on sexual violence during armed conflict. The resulting report (McDougall, 1998) documented, for the first time, the basis for establishing the systematic use of rape in war as a crime in its own right.

The recent decisions by the ICTR and the ICTY further served to address gaps in international legal conceptualizations of wartime rape as a crime against humanity. In 1998, the ICTR tried and convicted Jean-Paul Akeyesu, a Hutu mayor of a small Rwandan town, of genocide for knowingly allowing-and enabling - the 1994 mass rape of hundreds of Tutsi women. (Human Rights Watch, 1996, detailed the 1994 rape and genocide in Rwanda.) This case was the first step in prosecuting rape under international law; as such, it provided the groundwork for cases involving the widespread rape of Bosnian women that were subsequently considered by the ICTY (McHenry, 2002). Building on the Akeyesu decision, the ICTY in 2001 convicted three Bosnian Serb soldiers of crimes against humanity, 
including torture and rape, for their participation in a systematic campaign of rape and sexual enslavement involving approximately 20,000 Muslim women in Foca, a town in southeastern Bosnia-Herzegovina (see Human Rights Watch, 1998, for an account of the atrocities in Foca). The application of war crimes' standards to acts of rape established a precedent for prosecuting sexually related crimes in international law without violating state or individual sovereignty. It also created a basis for increasing the enforcement under international law of the protection of civilians, "especially those of different ethnicities, from even unsystematic acts of depravity during an armed conflict" and, in a nonessentializing manner, recognized that women are equal to men, rather than weaker beings in need of protection (McHenry, 2002, p. 1269). The evolution of legal conceptualizations of wartime rape as a crime in international law highlights the gendered nature of militarization and war but is beyond the scope of this article. (For further legal discussion and references on the topic, see McHenry, 2002; Russell-Brown, 2003.)

\section{Definition of Terms: Rape as a Weapon of War}

In the report prepared for the UN Commission on Human Rights, McDougall (1998, pp. 4-5) defined war rape as "a deliberate and strategic decision on the part of combatants to intimidate and destroy 'the enemy' as a whole by raping and enslaving women who are identified as members of the opposition group." The report went on to state the following:

"Rape" should be understood to be the insertion, under conditions of force, coercion, or duress, of any object, including but not limited to a penis, into a victim's vagina or anus; or the insertion, under conditions of force, coercion, or duress, of a penis into the mouth of the victim. Rape is defined in genderneutral terms, as both men and women are victims of rape. However, it must be noted that women are more at risk of being victims of sexually violent crimes and face gender-specific obstacles in seeking redress. (McDougall, 1998, p. 8)

The notion of "weapon of war" is not an explicit theme within political philosophical discourse or international political theorizing (Skjelsbaek, 2001). Proceeding from the common usage of the term, weapon is defined in Webster's Encyclopedic Unabridged Dictionary of the English Language (1997, p. 1616) as

1. any instrument or device for use in an attack or defense in combat, fighting, or war, as a sword, rifle, cannon, and so on;

2. anything used against an opponent, adversary, or victim; or

3. (Zool) any part or organ serving for attack or defense, as claws, horn, teeth, stings. 
Implicit in the conception of the systematic, intentional use of rape as a weapon is the notion of an attack on a civilian population. The ICTY proceedings established five elements of an attack:

1. there must be an attack,

2. the acts of the perpetrator must be part of the attack,

3. the attack must be directed against any civilian population,

4. the attack must be widespread or systematic,

5. the perpetrator must know of the wider context in which his acts occur and know that his acts are part of the attack. (Prosecutor v. Kunarac, 2001, para. 410)

Thus, an attack may be defined as a "course of conduct involving the commission of acts of violence" and will "normally be a pattern of conduct and not one particular act" (Prosecutor v. Kunarac, 2001, para. 415). Individual acts do not have to be "widespread or systematic" (Prosecutor v. Kunarac, 2001, para. 431); however, they must be part of a "course of conduct" in which the attack on a civilian population is so "widespread or systematic" that it can be prosecuted as a crime against humanity (McHenry, 2002; Prosecutor v. Kunarac, 2001, para. 427). The personal motives of the individual perpetrator are deemed to be irrelevant (McHenry, 2002, p. 1289); the perpetrator must "simply know that his actions occurred within the context of a broader attack on the civilian population" (Prosecutor v. Kunarac, 2001, para. 134). To fulfill the criteria for a crime against humanity, the attack must occur in the context of the armed conflict, which may also encompass the aftermath of conflict after hostilities have ended (McHenry, 2002, p. 1289).

The work of the ICTR and the ICTY has led to clearer definitions of the bounds of intolerable behavior by establishing the legal parameters through which wartime rape can be prosecuted as a crime against humanity, an act of genocide, or a war crime. Although these new legal parameters may not suffice actually to prevent future occurrences of war rape, their presence suggests that the international legal community will be less likely to ignore such acts.

Rape is both a weapon and a strategy of war. As a weapon, it "attacks women's physical and emotional sense of security while simultaneously launching an assault, through women's bodies, upon the genealogy of security as constructed by the body politic" (Koo, 2002, p. 525). As a strategy, it is a sanctioned, systematic means of attaining specific political objectives. Achieved by using war rape as an instrument of terror, domination, political repression, torture, intimidation, and humiliation, these objectives have at their heart control, compliance of civilians, and even genocide. Political ends include inciting ethnic hatred to accomplish ethnic cleansing and genetic imperialism as well as to destroy an enemy's cohesion, spirit, and identity. 


\section{THE CONTEXT OF WAR RAPE}

\section{Gender Relations, Patriarchy, and Militarization}

War-related gender violence builds on preexisting gender relations and sociocultural dynamics; it is the very concept of honor situated in women's bodies that makes wartime rape such an effective tool of terror (Menon \& Bhasin, 1998; Olujic, 1998). It may be helpful at this point to examine briefly the articulation of sexual violence during armed conflict with gender relations in times of both peace and conflict. Rather than focusing on armed conflict, which is a time-limited process, many feminists view the larger issue as militarization; after all, it is militaristic culture that legitimates violence as a way of solving conflict. The military, largely a masculine institution in terms of its members and policies, determines and reinforces hierarchies of power within and among states, thereby reinforcing and re-creating gender relations and patriarchy (Cockburn, 1999; Enloe, 1987; Kelly, 2000; OkazawaRey, 2002). One of the long-term effects of war is the militarization of society. A militarizing society calls on patriarchal values and mechanisms of domination and control, heightening hierarchical relations between men and women and equating constructions of masculinity with violence. The ways in which a society resolves its conflicts may be reproduced in the ways in which conflicts are resolved in the home, with a concomitant increase in sexual and domestic violence against women (Kelly, 2000; Levinson, 1989; McWilliams, 1998).

Many feminists regard gender relations as ongoing sites of conflict, with no clear peace for women whose security is threatened. War-related sexual violence, also constructed by and informed through gender, intersects with these ongoing sites of conflict (Kelly, 2000). Thus, wartime rape is viewed as an intensification, an extreme iteration, of the sexual violence that exists even when armed conflict is not present. Patriarchal hierarchies and values interact and intersect with militarization, fueling the construction of gender relations that underlie war rape. Protectionist values that are inherent in patriarchal relations promote views of women as men's property to be defended. As McDougall (1998) observed in her report to the UN Human Rights Commission on war rape, "Although this report retains 'penetration' in the definition of rape, it is clear that the historic focus on the act of penetration largely derives from a male preoccupation with assuring women's chastity and ascertaining paternity of children" (p. 8).

Religious and cosmological beliefs inform patriarchal theories of procreation that support these protectionist values. Constructions of procreation, within which the female body and the male's relation to it are symbolically understood, in turn structure gendered roles and relationships. For example, the female may be viewed as a vessel for the male seed-a construct that is central to the use of war rape in ethnic cleansing and to what Card (1996) termed "genetic imperialism." "Men are owners of the seed, in the form of 
both grain and children, and they control the seedbeds in which these are planted" (Delaney, 1991, p. 239). In this view, the woman provides the vessel for the seed and supplies nurturance from the field that is her body, whereas the male seed determines the identity of the child. Nations, as territory and as land, are often viewed symbolically as female, to be protected from outside forces, as can be demonstrated by appeals to save the honor of the motherland.

In this essentialist patriarchal construction, men are both the arbiters and the protectors of the boundaries for women and for nations. Thus, rape is not only an attack against women, it is also an assault on the honor of men, proving their inability to protect "their" women (Olujic, 1998). However, women also play a major role in constructing and defending ethnic and nationalist identity. As Yuval-Davis (1997) stated, women are the reproducers of the boundaries of ethnic and nationalist groups, through community control of their sexuality and honor, as situated in women's bodies. Women protect the honor of their community through marriage and cultural practices that maintain a pure lineage and pure ethnic-cultural identity. It follows, then, that rape and sexual violence during ethnic conflict become strategies for infiltrating or destroying these boundaries and attacking the honor of the community and the purity of its lineage. Thus, patriarchy alone does not adequately explain the selective targeting of women, determined, in part, by ethnic-cultural, national, and religious identities.

\section{Ethnic Cleansing and Genocide}

Focusing solely on the patriarchal aspects of war rape tends to essentialize women as victims because they are women. In many conflicts, however, women are selectively targeted according to their ethnicity and/or religion to attack the particular group genocidally through the women. In Taba (Rwanda) and Foca (Bosnia), for example, Tutsi and Bosnian Muslim women, respectively, were raped in systematic, genocidal assaults (Coomaraswamy, 1998; Stiglmayer, 1993). Thus, war rape is not just an attack on the male "territory" of assured female chastity, paternity, and procreative rights as constructed in patriarchal terms; it is also a strategy to carry out political objectives of ethnic cleansing (Mladjenovic, 1999; Olujic, 1998; Stiglmayer, 1993; UNICEF, 2000; Vickers, 1993) and genocide (Coomaraswamy, 1998). Ethnic cleansing is accomplished through a racist and genocidal intent to contaminate the enemy group's blood and genes. Rape as a weapon in this case is used in service of genetic imperialism (Card, 1996) by intentionally impregnating women of the enemy ethnic group. Under these circumstances, the perpetrators seek to dilute or "purify the blood" of the attacked group by creating "ethnically cleansed" children who belong to the invading group (Card, 1996; Olujic, 1998). As NikolicRistanovic (1999) noted, 
The idea of rape as a method of ethnic cleansing ... represents a deep patriarchal construction: women as objects, as passive recipients of men's seeds who add nothing original to it. In this view, the identity of the child depends only on men, and consequently, women impregnated by their enemies will give birth to children who will belong to the ethnic group of the enemy. (p. 78)

Some women were held in "rape camps" until they were in the late stages of pregnancy to ensure that they were not able to abort the fetuses (Stiglmayer, 1993). Others were forced to bear the children of war rape because of the lack of resources or because abortions were not available. In the former Yugoslavia, a rise in nationalism severely curtailed women's rights and access to abortion, forcing women to give birth following pregnancies resulting from interethnic rape; the church and major politicians largely contributed to the denial of previously guaranteed abortion rights (Nikolic-Ristanovic, 1999). Under these circumstances, rape was an effective tool for the reproduction of "ethnically cleansed" children. A further intent of war rape is genocide, carried out in Bosnia and Rwanda by rendering women physically unable to reproduce, incapable of bearing children. "In short, [the] purpose of ethnically organized rape is to destroy another ethnic group" (Olujic, 1998, p. 43) by any and all means possible.

\section{Targeting the Community}

War rape has devastating effects on a community, damaging community solidarity, destroying group spirit and moral strength (Card, 1996; Nordstrom, 1998; UNICEF 1996), and bringing about cultural collapse (Seifert, 1996). Hence, the widespread, intentional effects of war rape include the extreme disturbance created in a community that experiences mass sexual violence. Rape as a weapon is used to terrorize the population, forcing people to flee. Sexual terror and the appropriation of women's bodies thus aid the enemy to occupy and control the physical territory from which its targets have fled.

Wartime rape is often aimed at the destruction of group cohesion and the dissolution of a group's spirit, identity, and culture. Nordstrom (1998) noted the effectiveness of targeting moral strength and identity during the wartime violence that occurred in Mozambique: "The first time a Mozambican said to me that the war had taken from them everything they had, including who they were, I realized that identity, self, and personhood, as well as physical bodies, are strategic targets of war" (p. 105). Wartime rape not only damages group solidarity and individual identity, it may also have the effect of confusing loyalties, especially among the children of the survivors of rape (Card, 1996).

Sexual violation of women erodes the fabric of a community in a way that few weapons can. Rape's damage can be devastating because of the strong communal reaction to the violation and pain stamped on entire families. The harm 
inflicted in such cases on a woman by a rapist is an attack on her family and culture, as in many societies, women are viewed as repositories of a community's cultural and spiritual values (UNICEF, 1996, p. 1).

Thus, individual and group psyches can be undermined and destroyed by subjecting women to mass sexual violence. Genetic imperialism and ethnic cleansing do not refer just to the physical destruction of another ethnic group; they also entail shattering that group's core identity.

A social constructionist view of war rape offers a more complete explanatory framework than does patriarchy, which essentializes women, or the structuralist approach, which underlies the targeting of selective identity groups of women (Skjelsbaek, 2001). In the social constructionist perspective, wartime rape and sexual violence can be regarded as a "transaction of identities between the perpetrator and the victims; i.e., how their social identities become situated" (Skjelsbaek, 2001, p. 226). War rape as a form of conquest and control constitutes an assault on the honor of men and on their ability to protect "their" women-that is, their "property." It thus domesticates the men who are socially connected to the immediate victims: women survivors (Card, 1996). Men, too, may be directly targeted, and women may be perpetrators. The social constructionist perspective, then, can be summarized as follows:

The perpetrator, and his (potentially also her) ethnic/religious/political identity become masculinized, while the victim's ethnic/religious/political identity becomes feminized. Further, the masculinized and feminized identities are situated in a hierarchical power relationship, where masculinized identities are ascribed power and feminized identities are not. (Skjelsbaek, 2001, p. 226)

\section{RESPONSES TO WAR RAPE}

Across geographies of identity, agency, and purpose, women mobilize in response to war rape, with actions ranging from the immediate provision of services to building international court cases. Local women, survivors of war rape, and members of helping professions bring local nongovernmental organizations (NGOs) and clinics behind the front lines to meet the immediate needs of the survivors of war rape. International NGOs collaborate with these local partners, both directly and indirectly, often extending their services from humanitarian relief to longer-term development efforts. Alleviating devastating postwar conditions and developing adequate services become longer-term priorities in addition to addressing the ongoing medical and psychosocial needs of the survivors. International women's organizations proffer solidarity, consultation, training, and partnership in a variety of activities and types of presence in local settings. Particularly during the past decade, feminist jurists and activists have sought to document 
the atrocities and build cases to prosecute the perpetrators of war rape (e.g., through the ICTR, the ICTY, and human rights networks such as the UN Commission on Human Rights and Human Rights Watch).

\section{Local Responses}

Violated, terrorized, and often severely injured, survivors of war rape are faced with the immediate need for security, care, and sustenance. The longer-term sequelae of war rape include serious health consequences that gravely affect the recovery of social networks and communities. For example, numerous Rwandan survivors of the genocidal rapes have contracted HIV / AIDS and other sexually transmitted diseases (STDs); many were mutilated with severe and, for some, eventually fatal consequences (Coomaraswamy, 1998; Human Rights Watch, 1996, 2003). Others still suffer without adequate medical care. Compounding the injustice is the lack of antiretroviral drugs, which, Rwandan women's NGOs such as AVEGA AGAHOZA (Association of Widows of Genocide of 1994, founded in 1995) attest, should be the priority for survivors of rape without regard to their social or financial status (Gabiro, 2003; Kimani, 2003). AVEGA is one of the main organizations that assist women survivors in Rwanda; among its services is a medical clinic, which often lacks resources to provide medication other than painkillers. Because the clinic does not have antiretroviral treatment available, its efforts concentrate on treating opportunistic infections, especially because many survivors of rape have contracted HIV / AIDS and tuberculosis. In addition to exposure to STDs and HIV / AIDS, some women have children born from the rape.

Reflecting the difficult economic and social conditions that have persisted in Rwanda after the genocide, AVEGA also gives food rations and financial support to children. All-important family support networks were destroyed. Many women are the sole surviving members of their families. These survivors are now taking care of orphans from extended family members who lost their lives. The impact on the children has been substantial: loss, worries about their mothers' or caretakers' health, and apprehension about taking on adult responsibilities and growing up in child-headed households. Continued poverty results in malnutrition and the lack of medical treatment, which leads to more deaths. "We are dying. Slowly," said a rape survivor with AIDS, who is raising a child born out of the rape (Kimani, 2003). Death takes on a significance beyond the physical: the women's testimonies often die with them.

In Bosnia-Herzegovina, "women for women" aptly describes the policy of Medica Zenica, a center for traumatized displaced women. Staffed by Bosnian women physicians and other local professionals, the center treated more than 20,000 patients between 1993 and 1999 and provided therapy to more than 2,000 women (Medica Kosova, 1999; Walsh, 2000). During the 
subsequent crisis in Kosova, the team offered treatment to Kosovan refugees and helped Kosovan professionals establish a similar model known as Medica Kosova. The staff of Medica Zenica extended their expertise in psychosocial crisis intervention, training Kosovan and Albanian women who shared knowledge of similar languages, culture, and living conditions. Therapeutic principles implemented by these organizations include the following:

- Women who have been sexually abused need care in the first instance from women.

- They must be respected and their stories believed.

- Medical treatment should always be accompanied by social care.

- Self-healing is possible with the help of skilled, appropriate therapy. (Medica Kosova, 1999)

\section{Transnational Partnerships}

Direct intervention, advocacy, scholarship, documentation, and fund-raising are some of the many ways in which women outside the war zone express their solidarity with women who were raped during wartime. Partnering with local practitioners, many psychosocial and physical health professionals came from other parts of Europe to work with colleagues in countries that were formerly part of Yugoslavia. Medica Mondiale, based in Cologne, Germany, is an organization through which international women have been able to support local clinics and initiatives. Founded by a gynecologist working in Cologne, the organization raises funds and partners in the development of the local programs in Bosnia-Herzegovina, Kosova, and Albania mentioned earlier (Medica Mondiale, 2003a). Medica Mondiale also collaborates with women's organizations in Afghanistan and Iraq. Its partnership model includes the following activities:

- coordination of international appeals for funds;

- information campaigns, education, and advocacy to inform the public about the background issues and needs of women and girls in war and crisis zones and to prevent the further traumatization of women in medical and legal systems;

- the provision of services in areas of health, psychosocial support, counseling, shelters;

- the development of high-quality standards of treatment using the international interdisciplinary exchange of expertise;

- advocacy for traumatized women refugees not to be repatriated, especially in Germany;

- human rights campaigns: the promotion of women's rights as human rights;

- the deployment of exiled Afghan women medical professionals for short-term service in Afghanistan; 
- training in trauma work for women in health care and psychosocial service sectors;

- support of local feminist movements and organizations (Medica Mondiale, 2003b).

\section{Documentation of War Rape}

With the increasing publicity of war rape and its criminalization in international law, feminist legal and medical practitioners and advocates have engaged in substantial documentation efforts during and after recent conflicts. Because of the sensitivity of gathering and disseminating survivors' accounts, multifaceted approaches, such as that of Women's Rights International (WRI), are often essential. WRI, a U.S.-based international women's NGO, was launched in 1995 to help women in resource-poor settings document and address human rights violations against women during armed conflict or state-sponsored violence (Jennings \& Swiss, 2001). In 1997, WRI joined the Women's Health and Development Program (WHDP) at the Mother Patern College of Health Sciences in Monrovia, Liberia, in a multistage project that was designed to document the broad spectrum of wartime violence against Liberian women who were living in refugee camps in Côte d'Ivoire. In addition, the population-based survey documented the profound impact of the war in compromising women's educational status and economic self-sufficiency. The project incorporated advocacy and education with Liberian women on the effects of violence, as well as international activities to "focus attention on the pervasiveness of rape and other crimes against women during war and encourage agencies concerned with health, human rights, and development to support related projects" (WRI, 1999, pp. 1-2).

The WRI-WHDP collaboration underscores the importance of the local design and implementation of community surveys. Local leadership facilitated the incorporation of contextual and cultural information, the use of local languages, an awareness of sensitive topics, and an intimate knowledge of what is at stake for participants. The linkage of scholarship and activism is also a key element of the project's design. Thus, after the community survey of the incidence of wartime violence and its impact on women, the project staff conducted 2-week workshops with participants to address the effects of physical and sexual violence. These workshops, in turn, led to the organization of ongoing support groups to "promote mutual understanding, support, and willingness to speak for one another's rights" (Jennings \& Swiss, 2001, p. 303). Through these efforts, women in the camps organized, assumed elected leadership, and began to address concerns, such as violence against women, in the camps (Jennings \& Swiss, 2001; WRI, 1999). 


\section{IMPLICATIONS FOR PRACTICE AND THE PROFESSION}

As feminist social workers who are concerned with war rape and, by extension, with gender relations in militarizing societies, our tasks are complex and multifaceted. For many, the work requires internal reflection and reflexive practice so that one may truly ally with survivors of such sexual violence. We need to understand and dilute the mechanisms of denial and compartmentalization that artificially separate women in war zones from women allies who are living in relative zones of comfort and safety.

The work of the feminists on the front lines offers insights to the social work profession on how to practice social work, both in the war zones and with populations of refugees who may come from similar places. Women experience war rape against themselves or their compatriots not as an individual crime or as medicalized symptoms but within a sociopolitical-military context. Thus, women's organizations must not be narrowly service oriented; they need to engage in a range of strategies, from sensitive assessments to medical and psychosocial care in clinical and community contexts to economic well-being and feminist support. Militarized constructions of masculinity that equate violence with masculine identity also need to be challenged, suggesting that some of the work also needs to be with men. Documentation, legal action, and viewing war rape as a human rights issue and a crime are essential aspects of social work in the arena of war-related sexual violence.

As feminists with a global perspective, we need to interrogate the causal connections between burgeoning militarism and all forms of violence against women. We need to turn our attention to broadening our professional values and ethics to make them more inclusive of global issues, particularly with regard to gender relations and the discourse on gender, which largely take place outside the profession. As feminists in the United States and other countries whose policies propagate militarism across borders, we need to counter the privileged plaint that there is nothing one can do-that the problem is too massive or too inaccessible or too "other." We need to work proactively to understand and address forces of militarism and to desist from objectifying or "otherizing" war rape as a separate entity. We need to critically analyze policies that create conditions of war in the homes and homelands of women everywhere.

\section{REFERENCES}

Apple, B., \& Martin, V. (2003). No safe place: Burmese army and the rape of ethnic women. Washington, DC: Refugees International.

Archdiocese of Guatemala. (1999). Guatemala: Never again! REMHI, Recovery of Historical Memory Project: The official report of the Human Rights Office, Archdiocese of Guatemala. Maryknoll, NY: Orbis. 
Brownmiller, S. (1975). Against our will: Men, women, and rape. New York: Penguin Books.

Card, C. (1996). Rape as a weapon of war. Hypatia, 11(4), 4-18.

Chang, I. (1997). The rape of Nanking: The forgotten holocaust of World War II. New York: Basic Books.

Chinkin, C. (2001). Women's international tribunal of Japanese military sexual slavery. American Journal of International Law, 95, 335-342.

Cockburn, C. (1999, June 10-11). Gender, armed conflict, and political violence: Background paper. Washington, DC: World Bank.

Coomaraswamy, R. (1998). Report of the Special Rapporteur on violence against women, its causes and consequences (E/CN.4/1998/54). Geneva, Switzerland: United Nations.

Delaney, C. (1991). The seed and the soil: Gender and cosmology in Turkish village society. Berkeley: University of California Press.

Enloe, C. (1987). Feminist thinking about war, militarism, and peace. In B. Hess (Ed.), Analyzing gender: A handbook of social science research (pp. 526-547). Newbury Park, CA: Sage.

Enloe, C. (2000). Maneuvers: The international politics of women's lives. Berkeley: University of California Press.

Gabiro, G. (2003, November 21). Silent victims of Rwanda's genocide. Lausanne, Switzerland: Hirondelle News Agency. Retrieved from http://www.rwanda.net/english/News / news112003/news11212003b.htm

Geneva Convention Relative to the Protection of Civilian Persons in Time of War, August 12, 1949, art. 3, 6 U.S.T. 3516, 75 U.N.T.S. 287-288.

Human Rights Watch. (1996). Shattered lives: Sexual violence during the Rwandan genocide and its aftermath. Retrieved from http:/ / hrw.org/reports/1996/Rwanda.htm

Human Rights Watch. (1998). A closed dark place: Past and present human rights abuses in Foca. Retrieved from http:/ /www/hrw.org/reports 98/foca

Human Rights Watch. (2003). Policy paralysis: A call for action in HIV/AIDS-related human rights abuses against women and girls in Africa. Retrieved from http://www.hrw.org/reports/ 2003/africa1203

Jennings, P., \& Swiss, S. (2001, January 27). Health and human rights: Women and sexual violence-Supporting local efforts to document human-rights violations in armed conflict. The Lancet, 357(9252), 302-303.

Kelly, L. (2000). Wars against women: Sexual violence, sexual politics and the militarised state. In S. Jacobs, R. Jacobson, \& J. Marchbank (Eds.), States of conflict: Gender, violence and resistance (pp. 45-65). London: Zed Books.

Kimani, M. (2003, March 3). Killers come home: Hutus jailed for taking part in Rwanda's genocide are being resettled. Eight years on, will they be the hunted? Time International, 161(8), 34-35.

Koo, K. (2002). Confronting a disciplinary blindness: Women, war and rape in the international politics of security. Australian Journal of Political Science, 37, 525-536.

Legesse, A. (2000). Violations of human rights of civilians during the most recent phase of the EthioEritrean conflict. Asmara, Eritrea: Citizens for Peace in Eritrea.

Levinson, D. (1989). Family violence in cross-cultural perspective. Newbury Park, CA: Sage.

McDougall, G. (1998). Contemporary forms of slavery: Systematic rape, sexual slavery and slaverylike practices during armed conflict (E/CN.4/Sub.2/1998/13). Geneva, Switzerland: UN Sub-Commission on Prevention of Discrimination and Protection of Minorities.

McHenry, J. R., III. (2002). The prosecution of rape under international law: Justice that is long overdue. Vanderbilt Journal of Transnational Law, 35, 1249-1312.

McWilliams, M. (1998). Violence against women in societies under stress. In R. E. Dobash \& R. P. Dobash (Eds.), Rethinking violence against women (pp. 111-140). Thousand Oaks, CA: Sage.

Medica Kosova. (1999). Women for women. Retrieved from http:/ / www.socresonline.org.uk/ 4/2/appeal.html

Medica Mondiale. (2003a). Help amidst a hail of bombs. Retrieved from http://www. medicamondiale.org/html/werwirsind/_in/ind_wer_e.html

Medica Mondiale. (2003b). War is always violence against women. Retrieved from http:/ / www. medicamondiale.de/html/waswirtun/waswirtun_e.html

Menon, R., \& Bhasin, K. (1998). Borders and boundaries: Women in India's partition. New Delhi, India: Kali. 
Mladjenovic, L. (1999). Beyond war hierarchies: Belgrade feminists' experience working with female survivors of war. Women $\mathcal{E}$ Therapy, 22(1), 83-89.

Nikolic-Ristanovic, V. (1999). Living without democracy and peace: Violence against women in the former Yugoslavia. Violence Against Women, 5(1), 63-80.

Nordstrom, C. (1998). Terror warfare and the medicine of peace. Medical Anthropology Quarterly, 12, 103-121.

Okazawa-Rey, M. (2002). Warring on women: Understanding complex inequalities of gender, race, class, and nation. Affilia, 17, 371-383.

Olujic, M. (1998). Embodiment of terror: Gendered violence in peacetime and wartime in Croatia and Bosnia-Herzegovina. Medical Anthropology Quarterly, 12, 30-46.

Prosecutor v. Kunarac, No. IT-96-23-T (ICTY February 22, 2001). Retrieved from http:// www.un.org/icty/ind-e.htm, sect. IV, para. 134, 402, 410, 415, 427, 431.

Russell-Brown, S. L. (2003). Rape as an act of genocide. Berkeley Journal of International Law, 21, 350-374.

Seifert, R. (1996). The second front: The logic of sexual violence in wars. Women's Studies International Forum, 19(1-2), 35-42.

Skjelsbaek, I. (2001). Sexual violence and war: Mapping out a complex relationship. European Journal of International Relations, 7, 211-237.

Stiglmayer, A. (1993). The war in the former Yugoslavia. In A. Stiglmayer (Ed.), Mass rape: The war against women in Bosnia-Herzegovina (pp. 1-34). Lincoln: University of Nebraska Press.

Twagiramariya, C., \& Turshen, M. (1998). "Favours" to give and "consenting" victims: The sexual politics of survival in Rwanda. In M. Turshen \& C. Twagiramariya (Eds.), What women do in wartime: Gender and conflict in Africa (pp. 101-117). London: Zed Books.

UNICEF. (1996). The state of the world's children: Sexual violence as a weapon of war. Retrieved from http:/ / www.unicef.org/sowc96pk/sexviol.htm

UNICEF. (2000). The state of the world's children: Undeclared war. Retrieved from http:/ / www. unicef.org/sowc00/uwar1.htm

Vickers, J. (1993). The impact of war on women. Development, 4, 35-40.

von Kerenshazy, J., Tekle, T., Higo, S., Gottlieb, P., \& Aradom, T. (2002, July). Eritrea: Military occupation, sexual violence, and HIV. Paper presented at AIDS Barcelona, XIV International AIDS Conference, Barcelona, Spain. Retrieved from http://www.aids2002.com/TCMS_Content/Presentations/20020726/thorf1466.pdf

Walsh, M. (2000). Aftermath: The role of women's organizations in postconflict Bosnia and Herzegovina (Working Paper No. 308). Washington, DC: USAID Center for Development Information and Evaluation.

Webster's Encyclopedic Unabridged Dictionary of the English Language. (1997). New York: Portland House.

Women's Rights International (WRI). (1999). Violence against women in times of war: A research study in Liberia. Washington, DC: International Center for Research on Women and the Centre for Development and Population Activities.

Yuval-Davis, N. (1997). Gender and nation. London: Sage.

Nancy Farwell, Ph.D., is an assistant professor at the School of Social Work, University of Washington, 4101 15th Avenue, NE, Seattle,WA 98105; e-mail:nfarwell@u.washington. edu. 